\title{
Weather and climate versus mortality in Lisbon (Portugal) since the 19th century
}

\author{
Maria João Alcoforado a, *, 1 , David Marques ${ }^{\text {a, }}$, , Ricardo A.C. Garcia ${ }^{\mathrm{a}, 1}$, Paulo Canário ${ }^{\mathrm{a}, 1}$, \\ Maria de Fátima Nunes ${ }^{b}$, Helena Nogueira ${ }^{c}$, Ana Cravosa ${ }^{\text {b }}$ \\ ${ }^{a}$ CEG/IGOT, Universidade de Lisboa, Edificio Fac. Letras, Alameda da Universidade, 1600-214 Lisboa, Portugal \\ ${ }^{\mathrm{b}}$ IHC, Grupo CEHFCi, Universidade de Évora, Palácio do Vimioso, Largo Marquês do Marialva, 8, 7000-554 Évora, Portugal \\ ${ }^{\mathrm{c}}$ Departamento de Geografia, CIAS, Universidade de Coimbra, Faculdade de Letras, Colégio de S. Jerónimo, 3004-530 Coimbra, Portugal
}

\section{A R T I C L E I N F O}

\section{Article history:}

Available online

\section{Keywords:}

Climate change

Heat waves

Health

Mortality rhythms

Southern Europe

Lisbon

\begin{abstract}
A B S T R A C T
A renewed interest on the impacts of climate change has spurred several studies on climate/health relationships. This study aims to detect and explain any changes in the relationships between climate and mortality in Lisbon from 1835 until 2012. The evaluation of mortality seasonal rhythms over time is based on the 100-Index per decades, annual Winter-Summer ratio, as well as other descriptive statistics. A change in the seasonal rhythm of mortality over the last 177 years was found. In the mid-19th century mortality peaked in summer, whereas in the 1890s and the 1900s there was slight monthly variability. On the contrary, a winter maximum has occurred since the 1940 s, although a secondary summer peak of mortality may emerge during the most severe heat-waves. Although long term positive temperature trends were confirmed, no systematic positive mortality trends were found in the last three decades. The results suggest that mortality rhythm changes during the 19th and 20th century are not directly related to climatic reasons alone (except in the case of extreme weather events), but rather to improvements in hygienic, sanitary and nutrition conditions and advances in medicine. However, given the possible increase of summer heat waves in the future, and individuals increasing vulnerability, particularly in urban areas, such secondary peaks of mortality will tend to happen more frequently, unless adaptation of populations to hotter conditions takes place and/or measures are taken to protect people from high temperatures.
\end{abstract}

(c) 2014 Elsevier Ltd. All rights reserved.

\section{Introduction}

The influence of weather on human health has been recognized as early as the 5 th-4th century BC by Hippocrates. The current discussion on climate change, particularly the global warming issues and the foreseen possible negative impacts on public health, has caused a renewed interest in these topics (Huang et al., 2011; McMichael \& Lindgern, 2011; Woodward et al., 2014). Some publications suggest that extreme weather events, such as heat waves, are (and will be) one of the main causes of high mortality peaks

\footnotetext{
* Corresponding author. Tel.: +351 217940218; fax: +351 217938690.

E-mail addresses: mjalcoforado@campus.ul.pt (M.J. Alcoforado), davidmgmarques@campus.ul.pt (D. Marques), rgarcia@campus.ul.pt (R.A.C. Garcia), paulocanario@campus.ul.pt (P. Canário), mfn@uevora.pt (M.F. Nunes), helenamarquesnogueira@hotmail.com (H. Nogueira), abcravosa@ gmail.com (A. Cravosa).

1 Co-lead authors.
}

(Intergovernmental Panel on Climate Change [IPCC], 2012, 2013; Johnson \& Wilson, 2009; Kovats \& Hajat, 2008; Waylen, Keellings, \& Qiu, 2012), e.g. the 2003 European heat wave and the 2010 Russian heat wave that resulted in tens of thousands of deaths (Robine, Cheung, Le Roy, Van Oyen, \& Herrmann, 2007). Hajat and Kosatky (2010) studied 64 sites in different geographic settings and have shown that "in almost half the locations, the risk of mortality increased between $1 \%$ and $3 \%$ per $1{ }^{\circ} \mathrm{C}$ change in (...) temperature". This study has been carried out mainly in urban areas that house $51.6 \%$ of world population; $10.2 \%$ of the urban population is over 60 years of age (United Nations [UN], 2013) and hence particularly vulnerable to extreme weather events (European Environment Agency [EEA], 2012). Moreover, the urban heat island effect enhances the temperature rise (Alcoforado \& Andrade, 2008; Barata et al., 2011; Merbitz, Buttstädt, Michael, Dott, \& Schneider, 2012). A recent temperature increase has been detected in most continental areas of the Northern hemisphere (IPCC, 2013) and it is expected that mortality will increase with progressive warming of the 
atmosphere (Almeida, Casimiro, \& Calheiros, 2010; Hajat, Vardoulaldis, Heaviside, \& Eggen, 2014). Moreover, according to Casimiro, Calheiros, Santos, and Kovats (2006), mortality caused by high temperatures in Lisbon (Portugal) will increase from 5.8 to 6 deaths per 100,000 inhabitants (in 1980-88) to 8.5-12.1 in 2020 and to a maximum of 29.5 in 2050, if no adaptation takes place. According to Hajat and Kosatky (2010) "measures designed to minimize heat islands in cities, to keep the interiors of buildings cool and to improve the general care of the elderly are likely to play a key role in reducing future heat burdens".

On the contrary, other authors state that there is insufficient evidence that climate change (more precisely global warming) has been affecting human health (Deschenes, 2012; Dessai \& Hulme, 2004; Ebi, 2014; Harlan \& Ruddell, 2011; McMichael \& Lindgern, 2011; Wardekker, Jong, Bree, Turkenburg, \& Sluijs, 2014). According to Deschenes (2012), the empirical identification of the response function linking extreme temperatures to health is difficult due to the nonlinearity and heterogeneity of the response functions. These can reflect complex relationships, misconstructions due to omitted variables bias, and secular or seasonality changes over time and across countries. Furthermore, very little is known about the health-preserving effects of adaptation in response to extreme temperatures.

Carson, Hajat, Armstrong, and Wilkinson (2006) showed that in London "there was a progressive reduction of temperature related deaths over the 20th century, despite an ageing population". The authors conclude that this trend reflects more favourable environmental, social and health care conditions. In accordance with the latter, Goklany (2009) states that the decreasing trend of mortality in the U.S. is mostly related with the reduction of vulnerability and Barreca, Clay, Deschenes, Greenstone, and Shapiro (2013) found "that the mortality effect of an extremely hot day declined by about 80\% between 1900-1959 and 1960-2004" in the U.S., partly due to the use of domestic air conditioning.

Furthermore, the relationship weather/mortality is not stable in time and depends also on the seasons. Any research on this topic must look into the seasonality of mortality rates and to compare them with changing temperature rates. Rau (2007) showed that mortality seasonality changes in place and in time. Since the mid 19th century a Winter maximum has occurred in most NorthEuropean and North-American countries. In half a century (between 1870 and 1920) this seasonal pattern changed in the U.K. into a Winter peak and a Summer low (Rau, 2007). This shift in such a short period is most probably due a "considerable improvement in hygiene which almost completely eradicated intestinal diseases" (Rau, 2007:30-31) and not necessarily to climate change alone.

Lisbon is located at $38^{\circ} 43^{\prime}$ latitude $\mathrm{N}$ and it lies on a hilly area on the northern bank of the Tagus estuary, $30 \mathrm{~km}$ to the east of the Atlantic (Fig. 1). Its climate is 'Mediterranean', with a dry Summer and rainfall occurring mostly in the cold season. Throughout the 20th century the social, economic and demographic changes were particularly significant in consequence of a fast moving urbanization process.

The main objectives of this paper are: (i) to retrieve mortality and climatic data of the early 19th century in Lisbon; (ii) to compare the seasonal rhythm of mortality and climatic variables over time and (iii) to look for causal relationships between climate and mortality and investigate if they have changed over time.

Data is described in the next section, followed by the methodology selected to assess seasonality of mortality and temperature trends throughout time and by the Results Section. The results are analyzed in Discussion Section and the main conclusions are presented in the last section.

\section{Data and methods}

Meteorological and mortality data pertaining to the early 19th century were compiled by Marino Miguel Franzini, a military, scientist and politician who restarted meteorological observations in Lisbon in the early 19th century, at the request of Bernardino Gomez, a doctor who strived to understand why the seasonal patterns of mortality in Portugal (attaining then a maximum in Summer) were different from those of Belgium and other countries of Northern and Western Europe, where a maximum in mortality occurred in Winter (Franzini, 1842). These old data were brought to

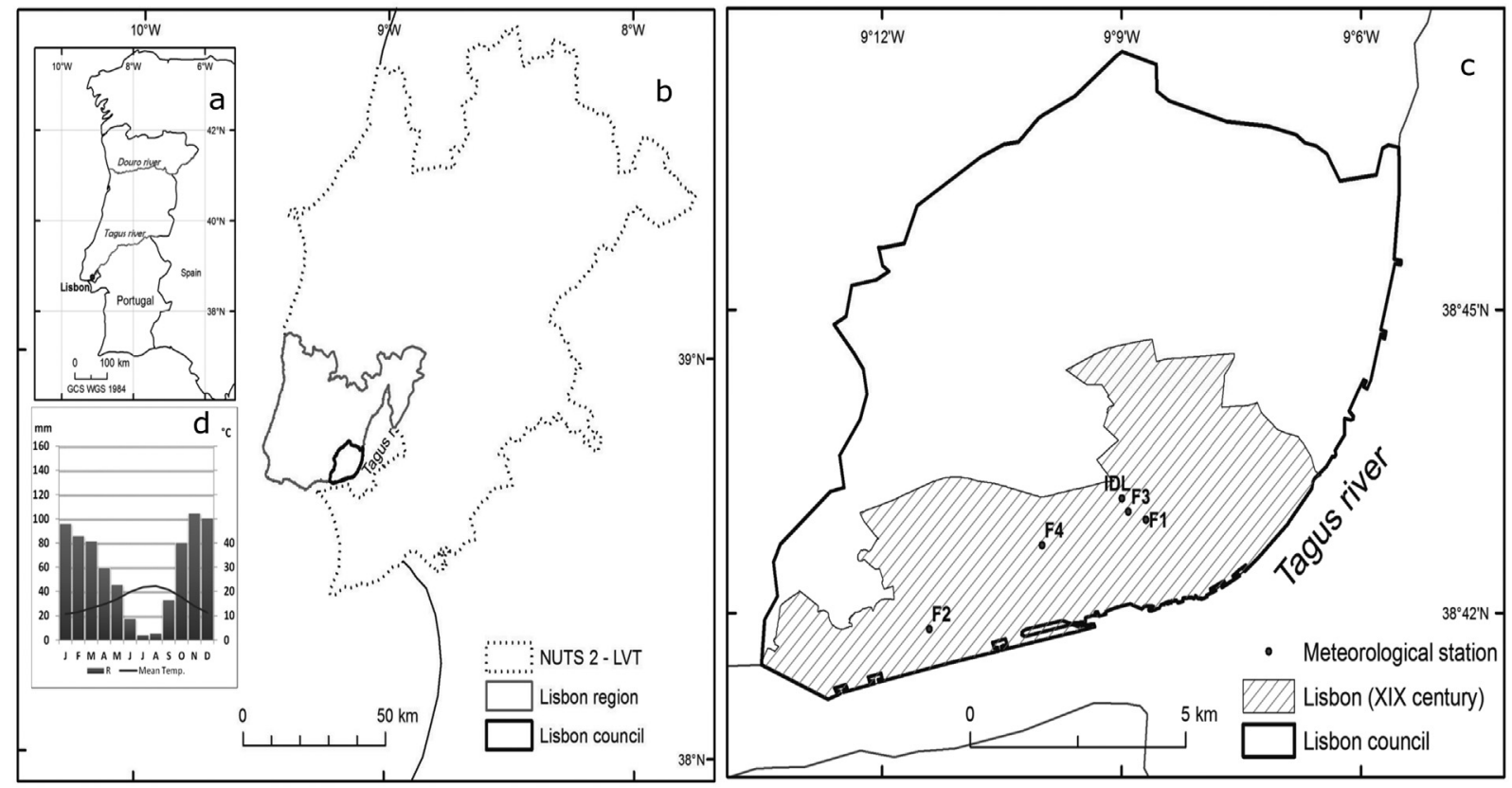

Fig. 1. Lisbon: Mortality data spatial units (a and b), meteorological station sites (c) and monthly temperature and precipitation chart (d). See also text and Table 2. 
Table 1

Lisbon mortality data: spatial coverage and sources.

\begin{tabular}{llll}
\hline Period & Spatial units & Source & \\
\hline $1835-1841$ & $\begin{array}{l}7 \text { parishes (including } \\
5 \text { urban parishes) }\end{array}$ & RUL/JMS & $\begin{array}{l}\text { Periodical Publications } \\
\text { (Franzini) }\end{array}$ \\
1843 & & RUL/JMS & \\
1845 & & RUL & \\
1849 & & RUL/LAS & \\
1855 & & DG & \\
1857 & & DG & \\
$1887-1896$ & Lisbon County & & Statistical Publications \\
$1901-1910$ & Lisbon Council & & (INE) \\
$1913-1925$ & Lisbon County & & \\
$1929-1987$ & & & \\
$1988-1989$ & Lisbon Region & & \\
$1990-1995$ & NUTS2 - Lisbon and & & \\
& Tagus Valley & & \\
$1996-2012$ & Lisbon Region & & \\
\hline
\end{tabular}

RUL: Revista Universal Lisbonense; JMS: Journal of Medical Sciences; LAS: Lisbon Academy of Sciences; DG: Diary of Government; INE: Statistics Portugal.

light during the project KLIMHIST: Reconstruction and model simulations of past climate in Portugal using documentary and early instrumental sources (17th-19th century, http://clima.ul.pt/ klimhist-project).

\section{Mortality data}

Franzini collected mortality data from Lisbon's parishes between 1835 and 1857 (albeit with some gaps); some of the records were published in newspapers, either technical (Journal of Medical Sciences, Royal Academy of Sciences, Government or general Publications (Revista Universal Lisbonense). The first official records of demographic data in Portugal published by the National Institute of Statistics (INE - Statistics Portugal) date back to 1887. However, some gaps in the mortality data still remain despite the official systematization of data collection in the early twentieth century. Nevertheless, it was possible to compile 129 complete years of monthly mortality data, starting in 1835 . This can be regarded as an illustrative and reliable data base of mortality distribution, once the aim of this work is not to calculate a mathematical trend for all the analysed period.

Nonetheless, mortality data do not always pertain to the same geographical area, which can range from small administrative units (parish) to large statistical units, such as the Nomenclature of Territorial Units for Statistics (NUTS) (Table 1; Fig. 1). In order to overcome the absence of exact spatial coincidence of mortality data throughout the series and to allow comparisons of seasonality in time, data were standardized and comparative tests were carried out in years for which data from different spatial units pertained to the same period of time (e.g., 1887, 1997).

Fig. 2 shows that the seasonal rhythm is similar in each period, regardless of the unit considered (NUTS2 Lisbon and Tagus Valley LTV, Lisbon Region and Lisbon Council), attesting that these spatial differences do not hinder the current research: in 1997, not only the differences are very small (maximum of $0.6 \%$ ), but also the seasonal rhythm is exactly the same with a pronounced Winter peak. In 1887, the curves are also comparable, although with higher values of mortality in Summer and Autumn (differences lower than 1\%).

\section{Climatic data}

There were hardly any meteorological observations in continental Portugal during the two decades that followed the early ones of the 1770s to the 1790s (Alcoforado, Vaquero, Trigo, \& Taborda, 2012). Marino Miguel Franzini's meteorological observations started in December 1815. His instruments, including their graduation scales, were carefully built and described as were the locations of the four Lisbon stations (Fig. 1c and Table 2). Data from the first two years (December 1815-December 1817) were published in the Memoirs of the Lisbon Academy of Sciences (Franzini, 1817, 1821).

From 1818 until 1826 and from 1835 until 1854 meteorological data were divulged in journals and newspapers (Table 2), together with data on mortality in some of Lisbon parishes. Two series of monthly meteorological data were compiled: 1815-1826 and 1835-1859 and the preliminary homogeneity analysis of monthly mean temperature series (Pettitt Test, Standard Normal Homogneity Test - SNHT, Buishand Test, Neumann Test) showed that the two series are not statistically different (Table A.1).

Between 1826 and 1835 there was a civil war in Portugal in which Franzini was involved; the war disrupted scientific research and it is the reason why there is a gap in the mortality data in that period. Official meteorological observations began in Lisbon in December 1854 at the Instituto Geofisico D.Luís (IDL) of the University of Lisbon, not far from two Franzini's stations (F1 and F3, Fig. 1, Table 2)

\section{Mortality time patterns}

The "100-Index" and Winter-Summer Ratio were deemed appropriate (e.g. Rau, 2007) to assess mortality seasonality and its changes over time (year and season). In fact, these indexes are used not only in historical demography surveys (Wrigley et al., 1997, cited in Rau, 2007), but also in contemporary mortality studies (Fargues \& Nassour, 1992, cited in Rau, 2007). "In 1912, Lucien March calculated an index for which he standardized the annual number of deaths to 1000" (Rau, 2007:40). Some recent studies
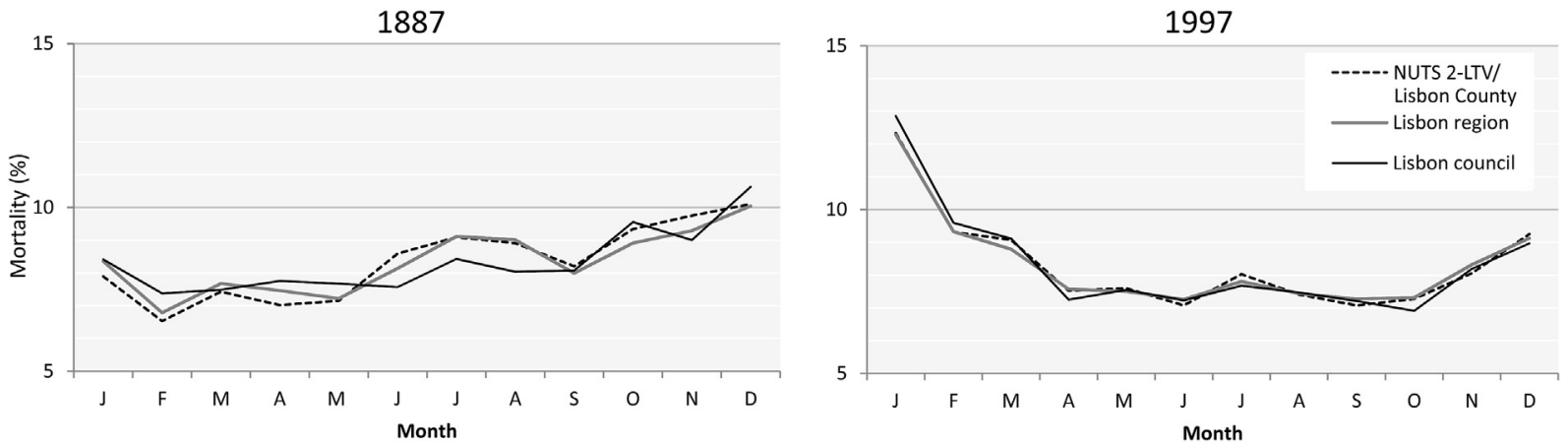

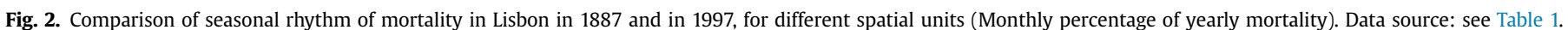


Table 2

Lisbon meteorological data from 1815 until present (see also Fig. 1c).

\begin{tabular}{|c|c|c|}
\hline Period & Station location in Lisbon & Source \\
\hline 1815 (December) & \multirow{2}{*}{ F1 - S. Pedro de Alcântara } & Franzini's Meteorological \\
\hline $1816-1820$ & & Observations (Periodical publications) \\
\hline $1821-1825$ & \multirow[t]{2}{*}{ F2 - R. Cordoaria da Junqueira } & \\
\hline 1826 (January to July) & & \\
\hline $1827-1834$ & Gap & \\
\hline 1835 (March to December) & \multirow[t]{3}{*}{ F3 - Patriarcal Queimada } & \\
\hline $1836-1843$ & & \\
\hline 1844 (January to August) & & \\
\hline 1847 (December) & \multirow[t]{4}{*}{ F4 - Calçada das Necessidades } & \\
\hline $1848-1853$ & & \\
\hline 1849 & & \\
\hline 1850 & & \\
\hline 1854 (December) & \multirow[t]{2}{*}{ F4 and IDL } & Franzini data, IDL publications and \\
\hline $1856-1859$ & & ECA \& D \\
\hline $1860-2012$ & IDL & IDL publications and ECA \& D \\
\hline
\end{tabular}

Fx: Franzini's stations; IDL: Dom Luiz Institute (WMO Station Code: 8535); ECA \& D: European Climate Assessment \& Dataset.

have replaced the radix 1000 by 1200 . "Thus, the expected number for each month in a uniform distribution is 100 which makes it more apprehensible for users of the decimal system" (Rau, 2007). The "100-index" $\left(\mathrm{I}_{100}\right)$ assumes that the annual value is equivalent to 1200 , i.e. in a non-seasonal series the $\mathrm{I}_{100}$ monthly value would be $100 . I_{100}$ is calculated as shown in Equation (1):

$I_{100}=\frac{X_{i}}{X_{\text {annual }}} \times 100$

where:

$\mathrm{I}_{100}-100$-index (mortality) of month $i$;

$X_{i}$ - Mortality of month $i$

$X_{\text {annual }}$ - Mean Annual mortality

The ratio between data of each month and the annual mean indicates if that specific month has recorded higher $\left(I_{100}>100\right)$ or lower $\left(I_{100}<100\right)$ values than would be expected in a non-seasonal series.

The Winter-Summer Ratio (W/S) allows the comparison of seasonal mortality over time, using Equation (2):

$W / S=\frac{\sum_{i=D E C}^{M A R} D_{i}}{\sum_{j=J U N}^{S E P} D_{j}}$

where:

W/S - Winter-Summer Ratio;

$D_{i}$ - Winter mortality (December, January, February and March);

$D_{j}-$ Summer mortality (June, July, August and September).

When the ratio is higher than 1 , Winter mortality $\left(D_{i}\right)$ is higher than Summer's one $\left(D_{j}\right)$, and vice-versa. Based on the literature (Falagas et al., 2009; Office for National Statistics [ONS], 2013), March was integrated in the Winter period (December-March) and September in the summer period (June-September). This decision was based on the typical climatic conditions of Mediterranean climate: in some years, extreme temperatures occur in these months, frequently associated with extreme events such as cold spells (in March) or heat waves (in September) that can cause a mortality excess. Moreover, the mean air temperature in September in Lisbon $\left(20.8^{\circ} \mathrm{C}\right)$ is higher than in June $\left(19.8^{\circ} \mathrm{C}\right)$. The inclusion of this month in the Summer period is also important due to the "September phenomenon in Mediterranean countries" (Falagas et al., 2009), i.e. the fact that September has the lowest mortality of the Summer period, provided that no heat waves occur in that month.

Summary statistics were further carried out to quantify W/S and $\mathrm{I}_{100}$ changes throughout time: the $\mathrm{W} / \mathrm{S}$ average and the $\mathrm{I}_{100}$ standard deviation by decade (Table A.2). Furthermore, Winter and Summer percentages of mortality were computed for each group of years, from the 19th century onwards, and are shown in Table A.3.

\section{Climatic time patterns}

Several studies have shown that temperature is one of the main climatic factors that influence mortality (Anderson \& Bell, 2009; Basu, 2009; D'Ippoliti et al., 2010; Guirguis, Gershunov, Tardy, \& Basu, 2014; Hajat \& Kosatky, 2010; Leone et al., 2013); therefore, Mann-Kendall tests (Kendall, 1975; Mann, 1945) were applied to the temperature series of Lisbon's meteorological station (IDL, 1856-2012, Table 2, Fig. 1) in order to determine the presence of a trend (Rau, 2007; Sousa, García-Barrón, \& Jurado, 2007). Man$\mathrm{n}$-Kendall tests are widely used in climatological data series trend analysis (Mavromatis \& Stathis, 2011) because they are nonparametric tests and hence have low sensitivity to abrupt breaks in non-homogeneous time series (Tabari, Marofi, Aeini, Talaee, \& Mohammadi, 2011). Daily maximum, minimum and mean temperature series went through the common quality control procedures and through several homogeneity tests (ECA \& D project). Two kinds of Mann-Kendall tests were used: the classic trend test and seasonal Mann-Kendall test, using XLSTAT software (a 0.05 level of significance was set for both tests).

Classical Mann-Kendall trend tests were performed for every month, throughout the period 1856-2012; series of mean, maximum and minimum temperatures, as well as extreme maximum (minimum) temperatures, e.g. the highest (lowest) temperature value within one month were analysed (Table A.4). Additionally the same test was run for the Summer season (not shown).

Seasonal Mann-Kendall tests accounts for seasonality by computing the test on a number of "seasons" defined by user and combining the results afterwards. January data will be compared only with January data, February with February, etc. In this analysis, month was defined as "season" and positive trends were found for maximum, minimum, mean and extreme maximum and minimum temperatures for the period 1856-2012 (Table A.5).

Concurrently and with the aim to analyse the variation of temperature extremes in Lisbon between 1835 and 2010, the 
frequency of days with particular air temperatures (Espírito Santo, Lima, Ramos, \& Trigo, 2014) was computed by decade (Table A.6) and for particular years (Table A.7), namely: Hot Days (TX25: maximum $>25{ }^{\circ} \mathrm{C}$ ), Very Hot Days (TX35: maximum $>35{ }^{\circ} \mathrm{C}$ ), Tropical Nights (TN20: minimum $>20^{\circ} \mathrm{C}$ ), Frosty Nights (minimum $<0{ }^{\circ} \mathrm{C}$ ), as well as the number of Cold Nights (minimum $<5{ }^{\circ} \mathrm{C}$ ).

\section{Results}

Overall mortality has been decreasing since the end of the 19th century and infant mortality in particular has decreased even faster. In the late nineteenth century (1887), Lisbon's Council mortality rate was $25.69 \%$, but infant mortality rate reached $235.2 \%$. In 1960 overall mortality had diminished to $10.5 \%$ (and infant mortality to $45.6 \%$ ); finally by 2013 mortality rates had dropped to $13.4 \%$ and infant mortality had further decreased to 3\%o (INE, 2013).

We did not calculate the mortality trends since 1835 , due to the gaps in our data between 1858 and 1886. The results would have been biased. However, in order to analyse if Summer mortality had any trend in recent decades (1980-2012) the classical Man$\mathrm{n}$-Kendall test was performed. As the computed p-value $(0.379)$ is greater than the significance level $\alpha=0.05$, the null hypothesis $\mathrm{H}_{0}$ (no trend in the series) is not rejected.

However, the seasonality of mortality changed throughout time. In the beginning of the 19th century, the peak of mortality occurred in Summer as opposed to what happened in the Northern European countries. In 1842, Franzini published data on mortality in Lisbon and in Belgium (Franzini, 1842). He compares mortality data from several parishes in Lisbon for the period 1837-1841 and for 10 years for "all cities in Belgium" as well (although Franzini does not name his source, nor does he identify the 10 year period). In order to show the difference in the seasonality of mortality in Portugal and in Belgium (Fig. A.1), we have calculated $\mathrm{I}_{100}$ index for Belgium and for the parishes Belem and Ajuda. The highest mortality in Lisbon in late Summer is clearly opposed to the Winter peak in Belgium.

The ratio between Winter and Summer mortality $(\mathrm{W} / \mathrm{S})$ has increased from mid-19th century onwards, although in a somewhat irregular way and with great inter-annual variability (Fig. 3). Until the beginning of the 20th century, mortality is most frequently higher in Summer than in Winter. As indicated in Table A.2, in the 19th century the values are lower than 1 (in the period of 1835-1860 the average was 0.92), showing that Summer mortality is higher than the Winter one. In the first decade of the 20th century, despite some years with $\mathrm{W} / \mathrm{S}$ lower than one, the $\mathrm{W} / \mathrm{S}$ average increased to 1.2, in what appears to be the beginning of the predominance of mortality during the Winter period (modern seasonal mortality pattern). The second-half of 20th century shows an increase of mortality during the Winter period with average W/S values around 1.3-1.4, more marked in the 1961-1970 and 1991-2000 decades. W/S was very high in 1918, due to the "Spanish flu" that increased considerably the number of deaths in Autumn and in Winter.

The $\mathrm{I}_{100}$, displayed in Fig. 4 for successive decades, confirms and provides more details about the seasonal and monthly variability of mortality. Fig. 4a shows data from the mid-19th century collected by Franzini and the Summer/Autumn maximum versus the Winter/ Spring minimum are apparent. Although average temperatures continue to peak in July and August (Fig. 4b), towards the end of the 19 th century mortality values vary little throughout the year. As time progresses maximum mortality shifts towards Winter, particularly after the 1940 s, and a Summer minimum is clear. The standard deviation of mortality $\mathrm{I}_{100}$ is the highest after the decade 1951-60 (Table A.2, with values between 15.3 and 17.4), while at the end of the 19th century the same parameter was 9.9, confirming that monthly mortality variability was smaller then.

In fact, the difference between Winter and Summer mean mortality percentage is lower than $3 \%$ (Table A.3) in the 19th century. Throughout the studied period, the relative importance of mortality in the Winter months increases $18 \%$ when compared with the 1st half of 19th century, whereas Summer mortality decreases $12 \%$ (Table A.3). Such evolution is also clear on a decadal basis (Fig. 4c and following ones).

The application of Mann-Kendall tests to the Lisbon's series (1856-2012) shows a positive trend for every temperature series (mean, maximum, minimum and maximum and minimum extreme temperatures) and every month and season (Table A.4 and A.5). The analysis of frequencies of maximum and minimum temperature extremes by decade in Lisbon (1839-2010) also shows that the 1940s was the warmest decade with the highest TX25 (1101 days) and TX35 (56 days) observed. An increase in the number of days with TX25, TX35 and particularly in the TN20 is evident since the 1980s (minimum temperature may still be increased due to urban heat island effect). On the other hand the number of frosty and cold nights (minimum $<5{ }^{\circ} \mathrm{C}$ ) have greatly decreased (Table A.6).

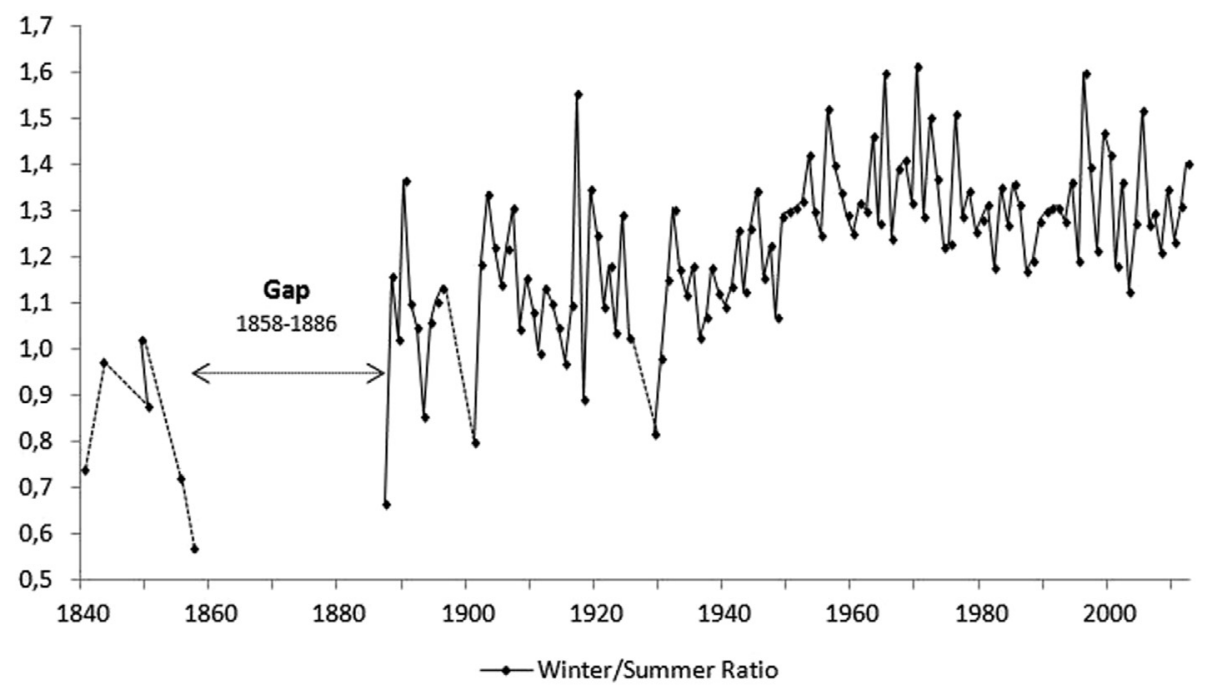

Fig. 3. Winter/Summer ratio of mortality in Lisbon (1840-2012). Data source: see Table 1. Solid line: no gaps; dashed line: gaps between yearly data. 


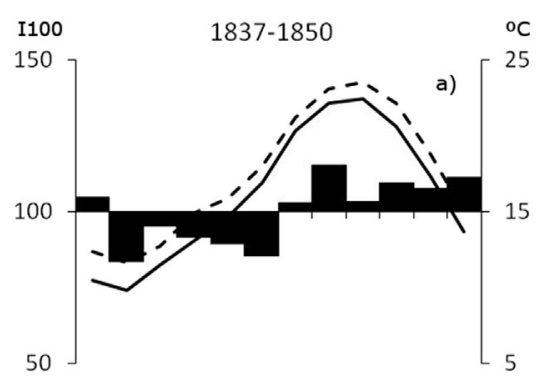

$1891-1896$
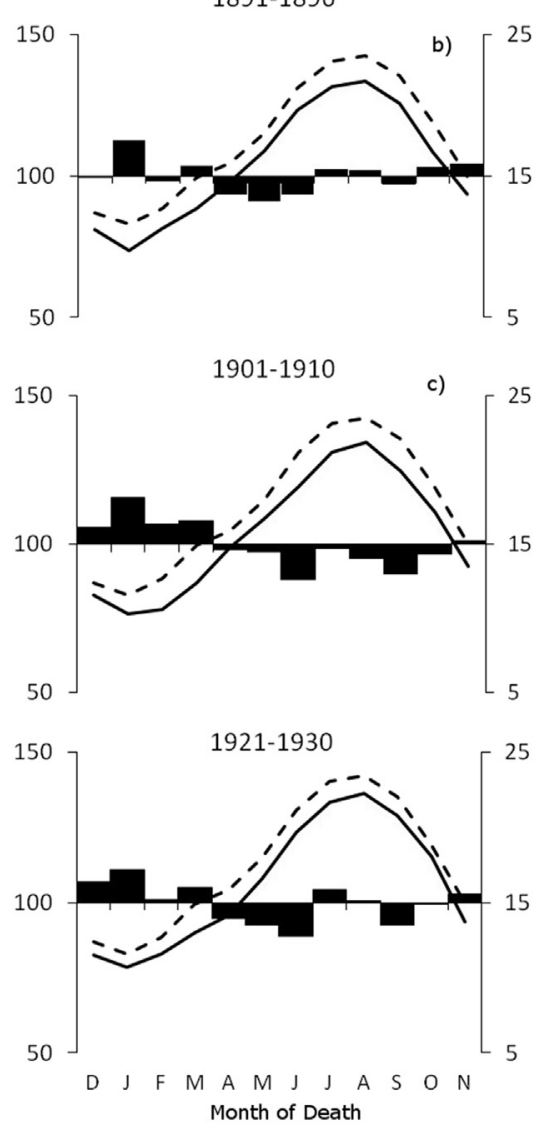

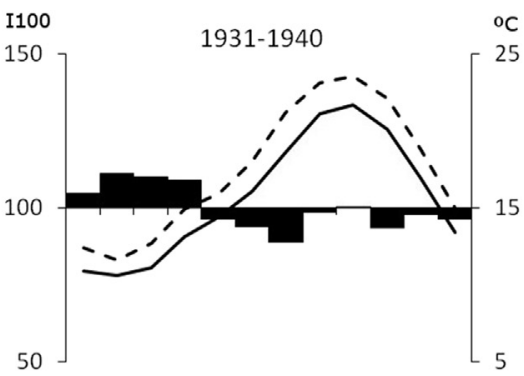

1941-1950

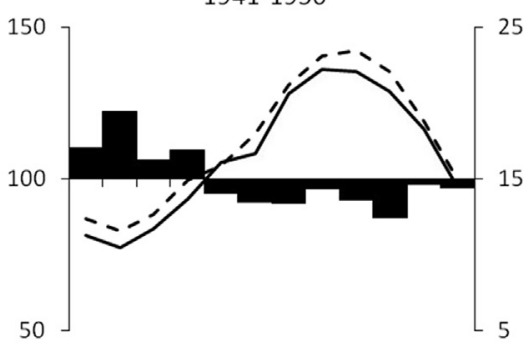

$1951-1960$
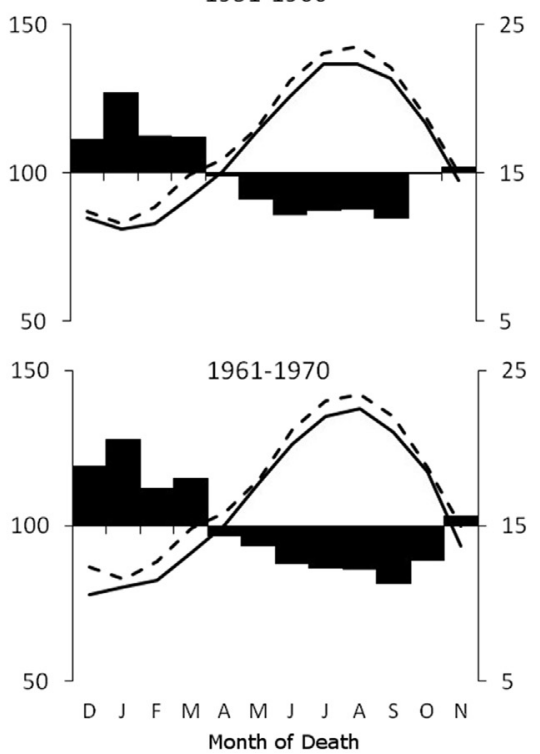
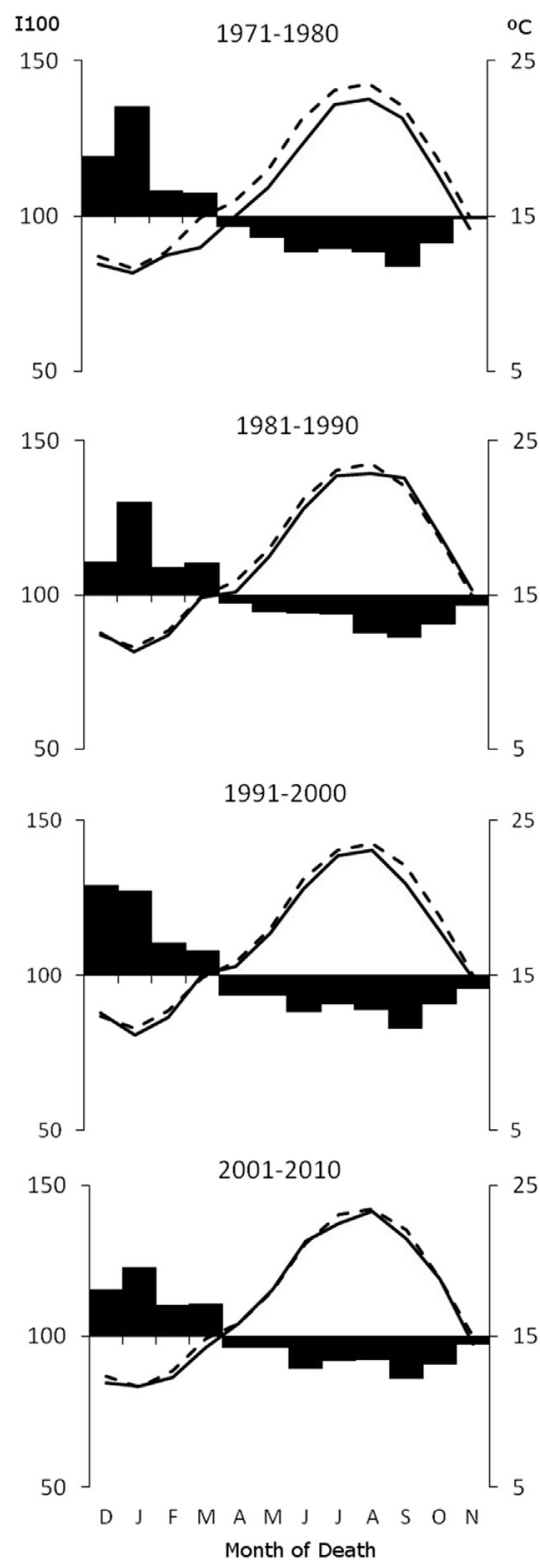

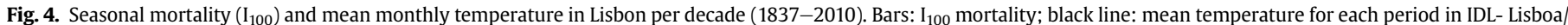

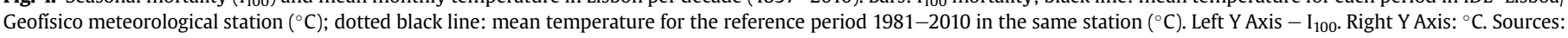
see Tables 1 and 2.

Notwithstanding this general evolution, some years may present a particular pattern of seasonal variability. Fig. 5 shows some years with different patterns of seasonal mortality, although the maximum temperature occurs always in July or August. 1850 is a typical year of the 19th century with maximum mortality in the Summer. 1887 shows the characteristics of a transition period between the 19th century and the current mortality patterns, whereas 2012 displays a more recent mortality pattern with a peak of mortality during Winter ( $\mathrm{I}_{100}$ of monthly mortality clearly higher than 100), regardless of the higher frequency of cold and frosty nights in 1850 or hot days in 2012 (Table A.7). In 2003, besides the Winter mortality peak, a secondary one occurs in August.

This is clear in the graphic for the year 2003, which is bi-modal, as the number of deaths increased in Summer: +395 deaths in August $\left(\mathrm{I}_{100}=115.1\right)$ in Lisbon most probably due or related to the heat wave (Botelho et al., 2004), as compared with August 2012 $\left(\mathrm{I}_{100}=90.2\right)$, that had a cool Summer and a "normal" seasonal mortality pattern. The 2003 heat wave in Lisbon lasted from July 29th until August 17th and was exceptionally hot with fifteen days registering maximum temperatures higher than $32^{\circ} \mathrm{C}$ (the average maximum temperature in Lisbon in August is $28.3^{\circ} \mathrm{C}$ ). In short, in a mortality modern pattern, there can be a secondary peak when severe Summer heat-waves occur. In recent years the secondary peak was clear in 2003 and 1981 heat-wave ( $I_{100}$ values $\left.>115\right)$. At the same time a smaller increase of mortality is identified during other heat-waves (with $\mathrm{I}_{100}$ slightly above than 100), such as July $1991\left(I_{100}=100.9\right)$, May $2001\left(I_{100}=104\right)$, July $2004\left(I_{100}=100\right)$ and July $2006\left(\mathrm{I}_{100}=100.6\right)$.

\section{Discussion}

There was undoubtedly a change of mortality seasonality throughout the last 177 years in Lisbon. In the 1850s the mortality peaked in the late Summer. According to Franzini, in Summer the 

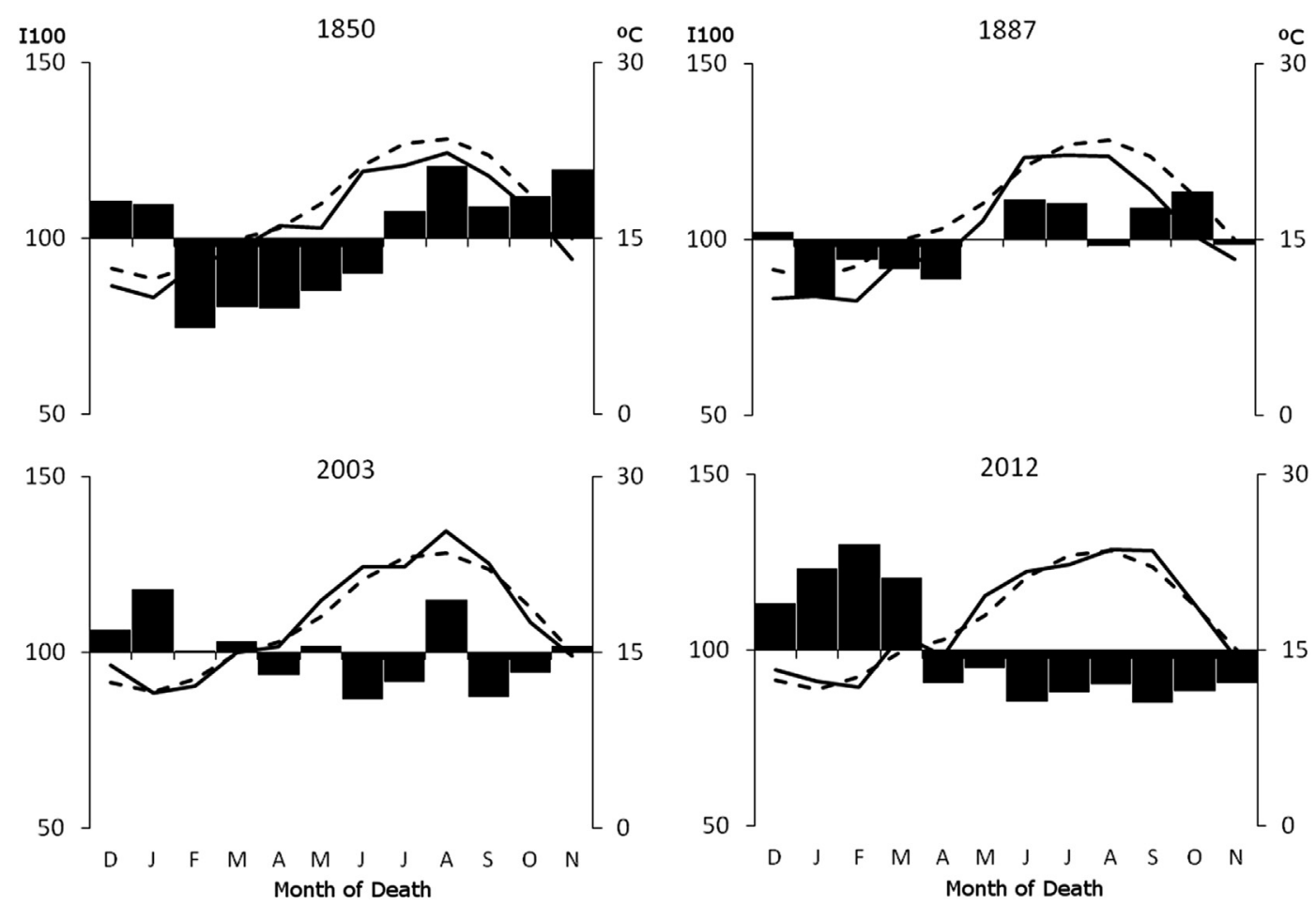

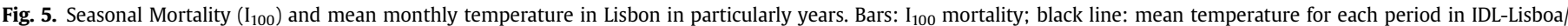

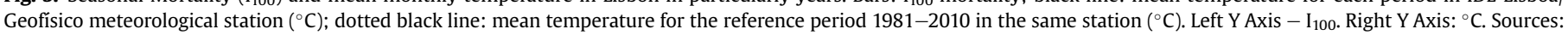
see Tables 1 and 2 .

less affluent classes consumed bad fruits, which induced serious gastric problems and fevers, which were also "due to exhalation of harmful gases that the intense heat and the very dry air produce in the low and swampy lands ..." (Franzini, 1842:493). At the end of the 19th century, mortality was quite uniform throughout the year and in the 20th century there was an increase in the Winter/Spring mortality. Omran (2005) summarized these changes by developing the theory of epidemiological transition that explains changes in patterns of health and disease based on interactions between these patterns and their demographic, economic and sociologic determinants and consequences.

Our results show that Portugal exhibited a "delayed" mortality pattern since the Summer peak of mortality still occurred in the mid-19th century, as opposed to what happened in most northern countries, such as England, Estonia and parts of France (Rau, 2007), where the transition occurred in the 17th and 18th centuries and southern countries, such as Italy, Spain and southern France, that had a Summer maximum mortality until the 18th century (Rau, 2007).

Several authors have shown the direct relationships between temperature and mortality (Hajat et al., 2014; Harlan \& Ruddell, 2011). As mentioned above, there was a significant positive trend of monthly maximum, minimum and mean temperature both on a yearly basis and by month (Table A.4 and A.5). Furthermore, the number of hot and very hot days and tropical nights has been increasing since mid 19th century and the number of cold and very cold nights has been diminishing (Table A.6). This could have increased Summer mortality and decreased the number of Winter deaths: we have shown that this was not the case. Therefore the main causes of these changes do not appear to be solely climatic.

During the 20th century, Portugal became an industrialized and urbanized country; this modernization process had important consequences in the decline of mortality rates (Nadal, 1988). Modernization brought about a change in mortality type from deaths of children due to transmissible, infectious pathologies (in Summer) to deaths of older people due to non-transmissible pathologies (in Winter) (Nazareth, 1996; Omran, 2005; Rau, 2007). In fact, until the beginning of the 20th century there was a high mortality rate of children up to 5 years of age, due to illnesses like gastroenteritis and enterocolitis that peaked in the Summer (Barbosa \& Godinho, 2001); these facts reveal the poor hygienic-sanitary infrastructures and the social and economic underdevelopment. As the Lisbon's swamps were dried, the malaria hazard decreased; this probably helped to accelerate the course of the epidemiological transition, by decreasing Summer mortality.

The "Summer" pattern gave way to the "Winter" one, characterized by deaths affecting mainly the elderly and largely caused by chronic and degenerative diseases. Donaldson and Keatinge (2002) and Lowen, Mubareka, Steel, and Palese (2007) state that influenza cannot explain Winter excess mortality in warmer Winters, as the virus transmission is boosted in colder weather as more people tend to gather indoors.

However, as mentioned above, a secondary Summer peak of mortality may occur associated with more intense heat waves. Assuming IPCC (2012, 2013) projections concerning the future increase of heat waves frequency, particularly in southern Europe, annual and even decadal mortality seasonal pattern may change again and become bi-modal, peaking in Winter and in Summer.

In this case, the causes of death will be strongly related to weather and climate, unless prevention and emergency plans (Nogueira \& Paixão, 2008), that already prevent many deaths, may be further improved and adapted to the various population groups with different vulnerabilities to extreme heat.

The urban heat island effect (Alcoforado \& Andrade, 2008; Alcoforado, Lopes, Alves, \& Canário, 2014; Johnson \& Wilson, 2009) and human activities may further increase high 
temperature and poor air quality hazards in the cities; moreover urban areas concentrates vulnerable population (from the economic, social and cultural points of view). As a result, risk of mortality is increased in urban areas (Canário, 2010; Johnson, Stanforth, Lulla, \& Luber, 2012). As risk varies a lot spatially, several studies are being developed to assess "place-based risk" (Hattis, OgnevaHimmelberger, \& Ratick, 2012; Johnson et al., 2012; Johnson \& Wilson, 2009; Waylen et al., 2012). An ongoing study of mortality per civil parish during heat waves in Lisbon's Metropolitan Area, which includes several cities (Andrade, Nogueira, \& Canário, 2012; Canário, 2010), has showed a large spatial diversity of mortality patterns related with age, health, living conditions, unemployment and poverty.

\section{Conclusion}

This study shows a definite modification of mortality seasonality throughout the last one and a half centuries in Lisbon and strongly suggest that the cause of seasonal mortality is not due to climate change alone.

In the 1850 s, mortality peaked in late Summer and at the end of the 19th century it remained quite uniform throughout the year, whereas in the 20th century there was a relative growth of Winter/ Spring mortality. In Portugal, the transition from Summer to Winter mortality occurred in the late 19th and beginning of the 20th centuries, contrasting with most European countries where the transition occurred earlier in time. The cause of this difference is probably related to the circumstance that demographic and socioeconomic changes, better hygienic, sanitary and nutrition conditions and advances in medicine occurred later in Portugal than in other western European countries.

Although there is a significant positive trend of monthly maximum temperature, which might be considered a cause for possible increase of Summer mortality, no Summer mortality trend was found in Lisbon in the last three decades.

Nevertheless, in years of maximum mortality in Winter, a secondary Summer mortality peak occurs occasionally in connection with intense heat waves. As the IPCC projects an increase of heat wave frequency in southern Europe and as urban population is increasing, it is possible that annual and even decadal mortality seasonal pattern may become bi-modal, peaking in Winter and in Summer. In this case, prevention and emergency plans should be further improved and adapted in order to deal with the population's vulnerability to extreme heat.

\section{Acknowledgements}

This research was carried out within the frame of the KLIMHIST Project: Reconstruction and model simulations of past climate in Portugal using documentary and early instrumental sources (17th-19th century) PTDC/AAC-CLI/119078/2010. We acknowledge Prof. Sandra Silva (UTAD University) for her help in statistical issues, Teresa Sutcliffe MSc for the English proof writing of this paper, and the data providers in the ECA\&D project (Klein Tank et al., 2002) Data and metadata available at http://www.ecad.eu. Thanks are also due to the anonymous referees, whose comments greatly contributed to improve the text.

\section{Appendix A. Supplementary data}

Supplementary data related to this article can be found at http:// dx.doi.org/10.1016/j.apgeog.2014.12.017

\section{References}

Alcoforado, M. J., \& Andrade, H. (2008). Global warming and urban heat island. In J. M. Marzluff, et al. (Eds.), Urban ecology (pp. 249-262). New York: Springer (Section III).

Alcoforado, M. J., Lopes, A., Alves, E., \& Canário, P. (2014). Lisbon's urban heat island Statistical study 2004-2012. Finisterra, XLVIII(98), 61-80.

Alcoforado, M. J., Vaquero, J. M., Trigo, R. M., \& Taborda, J. P. (2012). Early Portuguese meteorological measurements (18th century). Climate of the Past, 8(1), 353-371. http://dx.doi.org/10.5194/cp-8-353-2012.

Almeida, S. P., Casimiro, E., \& Calheiros, J. (2010). Effects of apparent temperature on daily mortality in Lisbon and Oporto, Portugal. Environmental Health, 9(12), 1-7. http://dx.doi.org/10.1186/1476-069X-9-12.

Anderson, B. G., \& Bell, M. L. (2009). Weather-Related Mortality. How heat, cold, and heat waves affect mortality in the United States. Epidemiology, 20(2), 205-213. http://dx.doi.org/10.1097/EDE.0b013e318190ee08.

Andrade, H., Nogueira, H., \& Canário, P. (2012). Utilização da análise multi-níveis para avaliação da vulnerabilidade da população da AML ao calor. Cadernos de Geografia, 30/31, 261-267.

Barata, M., Ligeti, E., De Simone, G., Dickinson, T., Jack, D., Penney, J., et al. (2011). Climate change and human health in cities. In C. Rosenzweig, et al. (Eds.) Climate change and cities: First assessment report of the UCCRN (pp. 179-213). Cambridge: Cambridge University Press.

Barbosa, M. H., \& Godinho, A. D. (2001). Crises de mortalidade em Portugal desde meados do século XVI até ao início do século XX. NEPS. Guimarães, Portugal: Universidade do Minho, ISBN 972-95433-1-3.

Barreca, A., Clay, K., Deschenes, O., Greenstone, M., \& Shapiro, J. (2013). Adapting to climate change: The remarkable decline in the U.S. temperature-mortality relationship over the 20th Century. MIT Department of Economics Working Paper N (pp. 12-29). Available http://papers.ssrn.com/sol3/papers.cfm?abstract id $=2192245$ Accessed 20.01.14.

Basu, R. (2009). High ambient temperature and mortality: a review of epidemiological studies from 2001 to 2008. Environmental Health, 8(40), 1-13. http:// dx.doi.org/10.1186/1476-069X-8-40.

Botelho, J., Catarino, J., Carreira, M., Calado, R., Nogueira, P. J., Paixão, E. J., et al. (2004). Onda de calor de Agosto de 2003: Os seus efeitos sobre a mortalidade da população portuguesa. INS Dr. Ricardo Jorge, ONSA, DGS. Lisbon: DGS.

Canário, P. (2010). Thermal extremes mortality risk assessment in urban areas. Finisterra, XLV(89), 171-177.

Carson, C., Hajat, S., Armstrong, B., \& Wilkinson, P. (2006). Declining vulnerability to temperature-related mortality in London over the 20th century. American Journal of Epidemiology, 164,(1), 77-84. http://dx.doi.org/10.1093/aje/kwj147.

Casimiro, E., Calheiros, J., Santos, F. D., \& Kovats, S. (2006). National assessment of human health effects of climate change in Portugal: approach and key findings. Environmental Health Perspectives, 114(12), 1950-1956. http://dx.doi.org 10.1289/ehp.8431.

Deschenes, O. (2012). Temperature, human health, and adaptation: A review of the empirical literature. NBER WP Publication no.w18345. Available http://ssin.com/ abstract $=2136014$ Accessed 10.01.14

Dessai, S., \& Hulme, M. (2004). Does climate adaptation policy need probabilities? Climate Policy, 4(2), 107-128.

Donaldson, G. C., \& Keatinge, W. R. (2002). Excess winter mortality: influenza or cold stress? Observational study. BMJ Clinical Research, 324, 89-90. http:// dx.doi.org/10.1136/bmj.324.7329.89.

D'Ippoliti, D., Michelozzi, P., Marino, C., Donato, F., Menne, B., Katsouyanni, K., et al. (2010). The impact of heat waves on mortality in 9 European cities: results from the EuroHeat project. Environmental Health, 9(37), 1-9. http://dx.doi.org/ 10.1186/1476-069X-9-37.

Ebi, K. (2014). Health in the new scenarios for climate change. International Journal of Environmental Research and Public Health, 11, 30-46. http://dx.doi.org 10.3390/ijerph110100030.

EEA (European Environment Agency). (2012). Challenges and opportunities for cities together with supportive national and European policies. EEA Report no.2/2012. Available http://www.eea.europa.eu/publications/urban-adaptation-toclimatechange Accessed 20.01.14.

Espírito Santo, F., Lima, M., Ramos, A., \& Trigo, R. (2014). Trends in seasonal surface air temperature in mainland Portugal, since 1941. International Journal of Climatology, 34(6), 1814-1837.

Falagas, M., Karageorpoulos, D., Moraitis, L., Vouloumanou, E., Roussos, N., Peppas, G., et al. (2009). Seasonality of mortality: the September phenomenon in Mediterranean countries. Canadian Medical Association Journal, 181(18), 484-486. http://dx.doi.org/10.1503/cmaj.090694.

Franzini, M., Observações Metéorologicas. Feitas na cidade de Lisboa no Anno de 1816 e 1817, Tomo V and VII, Parte II, Historia e Memorias da Academia Real das Sciencias de Lisboa 1817 and 1821 Typ. Academia, Lisbon.

Franzini, M. (1842). Reflexões sobre a influencia das estações na mortalidade dos habitantes de Lisboa. Revista Universal de Lisboa, 42,493-42,495. Retrieved from http://hemerotecadigital.cmlisboa.pt/OBRAS/RUL/18411842/Julho/N.\%C2\%BA\% 20042/RULN42.pdf Accessed 13.12.13.

Goklany, I. (2009). Deaths and death rates from extreme weather events: 1900-2008. Journal of American Physicians and Surgeons, 14(4), 102-109.

Guirguis, K., Gershunov, A., Tardy, A., \& Basu, R. (2014). The impact of recent heat waves on human health in California. Journal of Applied Meteorology and Climatology, 53, 3-19. http://dx.doi.org/10.1175/JAMC-D-13-0130.1. 
Hajat, S., \& Kosatky, T. (2010). Heat-related mortality: a review and exploration of heterogeneity. Journal of Epidemiology \& Community Health, 64(9), 753-760. http://dx.doi.org/10.1136/jech.2009.087999.

Hajat, S., Vardoulaldis, S., Heaviside, C., \& Eggen, B. (2014). Climate change effects on human health: projections of related mortality for the UK during the 2020's, 2050's and 2080's. Journal of Epidemiology \& Community Health, 68(7), 641-648. http://dx.doi.org/10.1136/jech-2013-202449.

Harlan, S., \& Ruddell, D. (2011). Climate change and health in cities: impacts of heat and air pollution and potential co-benefits from mitigation and adaptation. Current Opinion in Environmental Sustainability, 3(3), 126-134. http://dx.doi.org 10.1016/j.cosust.2011.01.001.

Hattis, D., Ogneva-Himmelberger, Y., \& Ratick, S. (2012). The spatial variability of heat-related mortality in Massachussetts. Applied Geography, 32, 45-52.

Huang, C., Barnett, A. G., Wang, X., Vaneckova, P., Fitzgerald, G., \& Tong, S. (2011) Projecting future heat-related mortality under climate change scenarios: a systematic review. Environmental Health Perspectives, 119(12), 1681-1690. http://dx.doi.org/10.1289/ehp.1103456.

INE. (2013). National institute of statistics survey homepage. Retrieved from http:// www.ine.pt/xportal/xmain?xpgid=inemain\&xpid=INE Accessed 10.12.13.

IPCC. (2012). Managing the risks of extreme events and disasters to advance climate change adaptation. Cambridge, UK: Cambridge University Press, $582 \mathrm{pp}$.

IPCC. (2013). Climate change 2013: The physical science basis. WG I, Fifth AR of the IPCC. Cambridge: Cambridge University Press, 1535 pp.

Johnson, D. P., Stanforth, A., Lulla, V., \& Luber, G. (2012). Developing an applied extreme heat vulnerability index utilizing socioeconomic and environmenta data. Applied Geography, 35, 23-31.

Johnson, D. P., \& Wilson, S. W. (2009). The socio-spatial dynamics of extreme urban heat events: the case of heat related deaths in Philadelphia. Applied Geography, 29, 419-434.

Kendall, M. G. (1975). Rank correlation methods (4th ed.). London, UK: Griffin.

Klein Tank, A. M. G., Wijngeard, J. B., Können, G. P., Böhm, R., Demarée, G. Gocheva, A., et al. (2002). Daily dataset of 20th century surface air temperature and precipitation series for the European Climate Assessment. International Journal of Climatology, 22, 1441-1453.

Kovats, R. S., \& Hajat, S. (2008). Heat stress and public health: a critical review Annual Review of Public Health, 29, 41-55. PMID: 18031221.

Leone, M., D'Ippoliti, D., De Sario, M., Analitis, A., Menne, B., Katsouvanni, K., et al. (2013). A time series study on the effects of heat on mortality and evaluation of heterogeneity into European and Eastern-Southern Mediterranean cities: results of EU CIRCE project. Environmental Health, 12, 55. http://dx.doi.org 10.1186/1476-069X-12-55.

Lowen, A. C., Mubareka, S., Steel, J., \& Palese, P. (2007). Influenza virus transmission is dependent on relative humidity and temperature. PLoS Pathogens, 3(10), e151. http://dx.doi.org/10.1371/journal.ppat.0030151.

Mann, H. B. (1945). Non-parametric tests against trend. Econometrica, 13, 245-259.
Mavromatis, T., \& Stathis, D. (2011). Response of the water balance in Greece to temperature and precipitation trends. Theoretical and Applied Climatology, 104, 13-24. http://dx.doi.org/10.1007/s00704-010-0320-9.

McMichael, A. J., \& Lindgern, E. (2011). Climate change: present and future risks to health, and necessary responses. Journal of Internal Medicine, 270,401-270,413. http://dx.doi.org/10.1111/j.1365-2796.2011.02415.x.

Merbitz, H., Buttstädt, Michael, S., Dott, W., \& Schneider, C. (2012). GIS_based identification of spatial variables enhancing heat and poor air quality in urban areas. Applied Geography, 33, 94-106.

Nadal, J. (1988). La población española (siglos XVI a XX) (3ª ed.). Barcelona: Editorial Ariel.

Nazareth, J. (1996). Introdução à Demografia - Teoria e Prática. Lisbon: Editorial Presença.

Nogueira, P., \& Paixão, E. (2008). Models for mortality associated with heatwaves: update of the Portuguese heat health warning system. International Journal of Climatology, 28(4), 545-562. http://dx.doi.org/10.1002/joc, 1546.

Omran, A. (2005). The epidemiological transition: a theory of the epidemiology of population change. Milbank Quaterly, 83(4), 731-757. http://dx.doi.org/10.1111/ j.1468-0009.2005.00398.x.

ONS (Office for National Statistics). (2003). Excess Winter mortality in England and Wales, 2012/13 (Provisional) and 2011/12 (Final). Statistical Bulletin. Available http://www.ons.gov.uk/ons/dcp171778_337459.pdf Accessed 30.04.13.

Rau, R. (2007). Seasonality in human mortality - A demographic approach. In Demographic research monographs (Vol. 3, p. XVI). Berlin: Springer.

Robine, J. M., Cheung, S. L., Le Roy, S., Van Oyen, H., \& Herrmann, F. R. (2007). Report on excess mortality in Europe during Summer 2003. Available http://ec.europa.eu/ health/ph_projects/2005/action1/docs/action1_2005_a2_15_en.pdf Accessed 10.03.14.

Sousa, A., García-Barrón, L., \& Jurado, V. (2007). El cambio climático en andalucía: Evolution y consequencias medioambientales. Sevilla: Consejería de Medio Ambiente Junta de Andalucía.

Tabari, H., Marofi, S., Aeini, A., Talaee, P. H., \& Mohammadi, K. (2011). Trend analysis of reference evapotranspiration in the western half of Iran. Agricultural and Forest Meteorology, 151(2), 128-136. http://dx.doi.org/10.1016/ j.agrformet.2010.09.009.

UN (United Nations). (2013). Urban and rural population by age and sex, 1980-2015. Available http://esa.un.org/unpd/popdev/urpas/urpas.html Accessed 10.01.14.

Wardekker, J. A., Jong, A., Bree, L., Turkenburg, W., \& Sluijs, J. (2014). Health risks of climate change: an assessment of uncertainties and its implications for adaptation policies. Environ Health, 11, 67. http://dx.doi.org/10.1186/1476-069X-11-67.

Waylen, P., Keellings, D. \& Oiu, Y. (2012). Climate and health in Florida: changes in risks of annual maximum temperatures in the second half of the 20th century. Applied Geography, 33, 73-81.

Woodward, A., Smith, K., Campbell-Lendrum, D., Chadee, D. D., Honda, Y., Liu, Q., et al. (2014). Cliamte change and health: on the latest IPCC report. Lancet, 383(9924), 1185-1189. http://dx.doi.org/10.1016/S0140-6736(14)60576-6. 


\title{
$\underline{\text { Appendix }}$
}

\section{Weather and climate versus mortality in Lisbon (Portugal) since the 19th century}

\author{
Maria João Alcoforado, David Marques, Ricardo Garcia, Paulo Canário, Fátima Nunes, \\ Helena Nogueira and Ana Cravosa
}

\section{Table of Contents}

\section{Figures:}

Figure A.1 "100 index" for 10 cities in Belgium and for the parishes of Belem and Ajuda (Lisbon- 18371841). No time period available for the Belgium cities. Data source: Franzini (1842).-----------2

\section{Tables:}

Table A.1 Homogeneity tests of mean monthly temperature from two Lisbon temperature series (18151826 and 1835-1859). Data collected by Franzini. Data sources: see Table 2.-------3

Table A.2 Mortality in Lisbon during the period 1837-2012: Winter/Summer ratio (W/S) average and I100 standard deviation by decades. Data source: see Table 1 $-3$

Table A.3 Mean percentage of seasonal mortality in Lisbon. Winter (Dec-Mar), Summer (Jun-Set). Data source: see Table 1 $-4$

Table A.4 Monthly Mann-Kendall trend tests for maximum, minimum and mean temperature (Lisbon1856-2012). Data source: see Table 2. $-5$

Table A.5 Annual Mann-Kendall trend tests for several temperature parameters (Lisbon- 1856-2012). Data source: see Table 2. $-5$

Table A.6 Frequencies of maximum and minimum temperature extremes by decade (Lisbon 1839-2010). Data source: see Table 2. $--6$

Table A.7 Frequencies of maximum and minimum temperature extremes in some years in Lisbon. Data source: See Table 2. $--6$ 


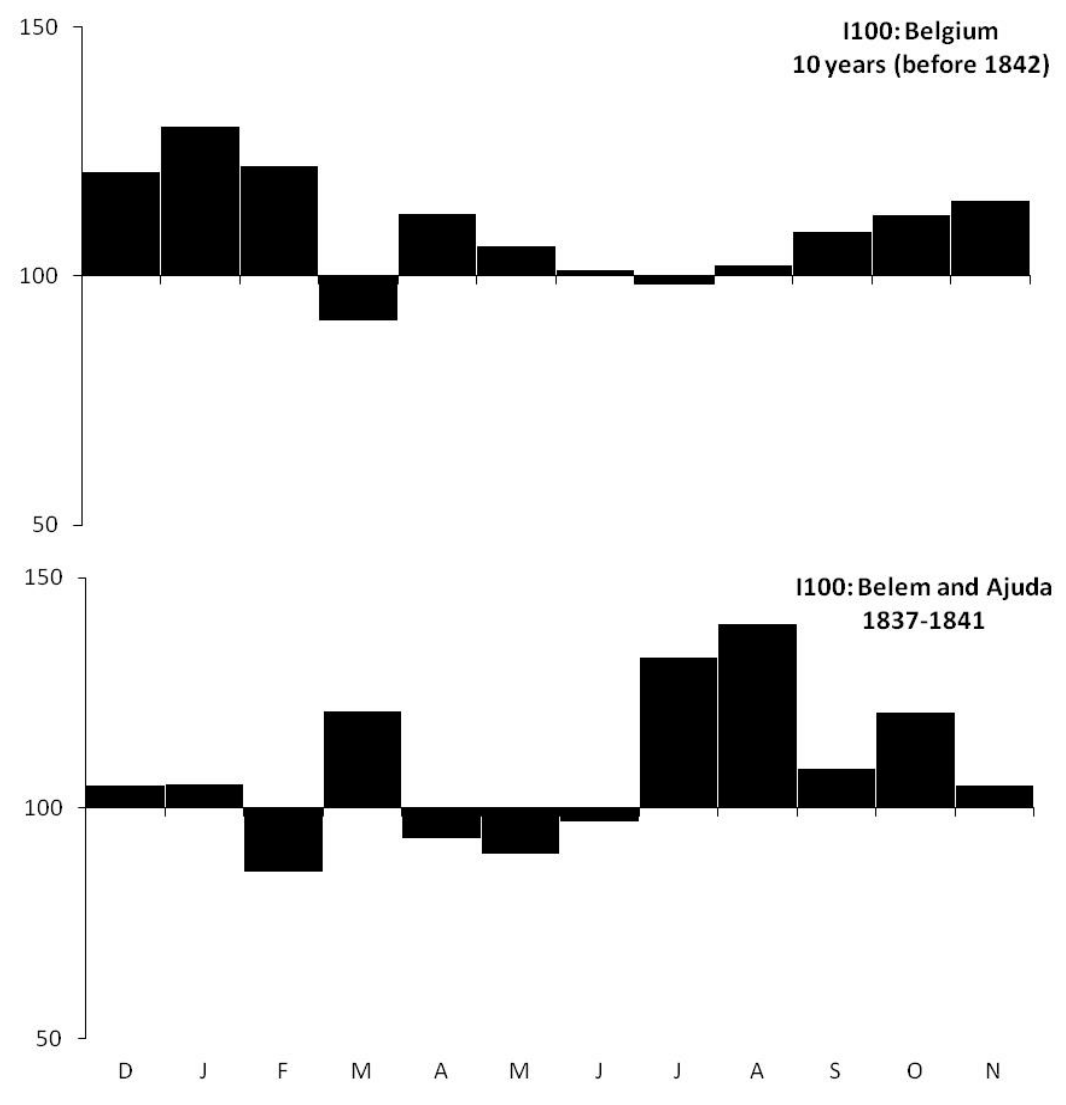

Figure A.1 "100 index" for 10 cities in Belgium and for the parishes of Belem and Ajuda (Lisbon- 1837-1841). No time period available for the Belgium cities. Data source: Franzini (1842). 
Table A.1 Homogeneity tests of mean monthly temperature from two Lisbon temperature series (1815-1826 and 1835-1859). Data collected by Franzini. Data sources: see Table 2.

\begin{tabular}{ccccc}
\hline Months & $\begin{array}{c}\text { Pettitt } \\
\text { Test }\end{array}$ & $\begin{array}{c}\text { Standard Normal } \\
\text { Homogeneity Test } \\
\text { (SNHT) }\end{array}$ & $\begin{array}{c}\text { Buishand } \\
\text { Test }\end{array}$ & $\begin{array}{c}\text { von Neumann } \\
\text { Test }\end{array}$ \\
\hline Jan & 0.33 & 0.76 & 0.65 & 0.79 \\
Feb & 0.65 & 0.45 & 0.41 & 0.56 \\
Mar & 0.62 & 0.44 & 0.32 & 0.59 \\
Apr & 0.25 & 0.43 & 0.22 & 0.29 \\
May & $0.04 *$ & 0.06 & 0.06 & $0.01^{*}$ \\
Jun & 0.94 & 0.72 & 0.82 & 0.82 \\
Jul & 0.62 & 0.32 & 0.53 & 0.50 \\
Aug & 0.10 & 0.25 & 0.21 & 0.19 \\
Sep & 0.12 & 0.43 & 0.16 & 0.35 \\
Oct & 0.59 & 0.79 & 0.65 & 0.65 \\
Nov & 0.56 & 0.37 & 0.57 & 0.39 \\
Dec & 0.82 & 0.97 & 0.97 & 0.98 \\
\hline \multicolumn{2}{l}{ Note: $p$-value $<0.05$ for all tests except when marked $*\left(\mathrm{H}_{0}\right.$ not rejected) }
\end{tabular}

Table A.2 Mortality in Lisbon during the period 1837-2012: Winter/Summer ratio (W/S) average and $\mathrm{I}_{100}$ standard deviation by decades. Data source: see Table 1.

\begin{tabular}{ccc}
\hline Decades & $\begin{array}{c}\text { Average } \\
\text { W/S }\end{array}$ & $\begin{array}{c}\text { Standard Deviation } \\
\mathbf{I}_{\mathbf{1 0 0}}\end{array}$ \\
\hline $1837-1860$ & 0.9 & 11.3 \\
$1891-1896$ & 1.1 & 9.9 \\
$1901-1910$ & 1.2 & 10.8 \\
$1921-1930$ & 1.1 & 12.6 \\
$1931-1940$ & 1.1 & 9.6 \\
$1941-1950$ & 1.2 & 12.1 \\
$1951-1960$ & 1.3 & 15.3 \\
$1961-1970$ & 1.4 & 16.8 \\
$1971-1980$ & 1.3 & 16.3 \\
$1981-1990$ & 1.3 & 15.3 \\
$1991-2000$ & 1.4 & 17.4 \\
$2001-2020$ & 1.3 & 13.1 \\
\hline
\end{tabular}


Table A.3 Mean percentage of seasonal mortality in Lisbon. Winter (Dec-Mar), Summer (Jun-Set). Data source: see Table 1.

\begin{tabular}{lccc}
\hline \multicolumn{1}{c}{ Period } & \multicolumn{2}{c}{ Mean Mortality Percentage } \\
\multicolumn{1}{c}{ \# years } & Winter & Summer \\
\hline 19th century - 1st half (a) & 8 & 32.7 & 33.8 \\
19th century - 2nd half & 9 & 35.2 & 32.4 \\
20th century - 1st half & 42 & 35.8 & 31.0 \\
20th century - 2nd half & 50 & 39.0 & 29.2 \\
Beginning of 20th century (b) & 12 & 38.5 & 29.8 \\
Beginning of 20th century (without heat-waves years) (c) & 9 & 39.2 & 29.6 \\
\hline Range (\%) (b/a) & & & \\
Range (without heat-waves years) (\%) (c/a) & & 17.7 & -11.8 \\
\hline
\end{tabular}


Table A.4 Monthly Mann-Kendall trend tests for maximum, minimum and mean temperature (Lisbon- 1856-2012). Data source: see Table 2.

\section{Mann-Kendall Statistics}

Month Max. temp. Min. temp. Mean temp. Positive trend

\begin{tabular}{ccccc}
\hline Jan & 7008 & 3789 & 4807 & Yes \\
Feb & 4864 & $2975^{*}$ & 3566 & Yes \\
Mar & 4522 & 5392 & 4843 & Yes \\
Apr & 3625 & $2890^{*}$ & 3229 & Yes \\
May & 3361 & $2811^{*}$ & 3251 & Yes \\
Jun & 3321 & $2805^{*}$ & $3063^{*}$ & Yes \\
Jul & $3686^{*}$ & $2586^{* *}$ & $3028^{*}$ & Yes \\
Aug & 3725 & $2863^{*}$ & 3947 & Yes \\
Sep & 4604 & 3085 & 4576 & Yes \\
Oct & 4622 & 3850 & 4965 & Yes \\
Nov & 4465 & 3126 & 3813 & Yes \\
Dec & 5779 & 4342 & 4751 & Yes
\end{tabular}

Note: $\mathrm{p}$-value $\overline{<0.0001 \text { for all tests except when marked } *(\mathrm{p} \text {-value }<0.001) \text { or } * *(\mathrm{p} \text {-value }<0.002)}$.

Table A.5 Annual Mann-Kendall trend tests for several temperature parameters (Lisbon-1856-2012). Data source: see Table 2.

\begin{tabular}{lccc}
\hline Response variable & MK statistic & p-value & Positive trend \\
\hline Maximum temperature & 1791 & 0.0060 & Yes \\
Average temperature & 5864 & $<0.0001$ & Yes \\
Minimum temperature & 3689 & $<0.0001$ & Yes \\
Extreme maximum temperature & 2384 & 0.0017 & Yes \\
Extreme minimum temperature & 3884 & $<0.0001$ & Yes \\
\hline
\end{tabular}


Table A.6 Frequencies of maximum and minimum temperature extremes by decade (Lisbon 1839-2010). Data source: see Table 2.

\begin{tabular}{cccccc}
\hline Decades & TX25 & TX35 & TN20 & TN $<\mathbf{0}^{\mathbf{0}} \mathbf{C}$ & TN $<\mathbf{5}^{\mathbf{0}} \mathbf{C}$ \\
\hline $\mathbf{1 8 3 9 - 1 8 5 0}$ & 609 & 27 & 59 & 8 & 178 \\
$\mathbf{1 8 6 1 - 1 8 7 0}$ & 966 & 15 & 139 & 1 & 147 \\
$\mathbf{1 8 7 1 - 1 8 8 0}$ & 577 & 14 & 74 & 0 & 175 \\
$\mathbf{1 8 8 1 - 1 8 9 0}$ & 579 & 15 & 77 & 4 & 189 \\
$\mathbf{1 8 9 1 - 1 9 0 0}$ & 774 & 17 & 119 & 1 & 113 \\
$\mathbf{1 9 0 1 - 1 9 1 0}$ & 681 & 14 & 106 & 0 & 101 \\
$\mathbf{1 9 1 1 - 1 9 2 0}$ & 717 & 19 & 123 & 0 & 76 \\
$\mathbf{1 9 2 1 - 1 9 3 0}$ & 769 & 31 & 168 & 1 & 85 \\
$\mathbf{1 9 3 1 - 1 9 4 0}$ & 668 & 20 & 61 & 3 & 155 \\
$\mathbf{1 9 4 1 - 1 9 5 0}$ & 1101 & 56 & 88 & 2 & 149 \\
$\mathbf{1 9 5 1 - 1 9 6 0}$ & 954 & 19 & 62 & 7 & 123 \\
$\mathbf{1 9 6 1 - 1 9 7 0}$ & 966 & 43 & 100 & 0 & 115 \\
$\mathbf{1 9 7 1 - 1 9 8 0}$ & 848 & 15 & 71 & 0 & 66 \\
$\mathbf{1 9 8 1 - 1 9 9 0}$ & 977 & 36 & 161 & 0 & 66 \\
$\mathbf{1 9 9 1 - 2 0 0 0}$ & 938 & 34 & 194 & 0 & 57 \\
$\mathbf{2 0 0 1 - 2 0 1 0}$ & 1042 & 40 & 217 & 0 & 66 \\
\hline
\end{tabular}

TX25: Hot days - Number of days with daily maximum temperature $>25^{\circ} \mathrm{C}$; TX35: Very hot days Number of days with daily maximum temperature $>35^{\circ} \mathrm{C}$; TN20: Tropical nights - Number of days with daily minimum temperature $>20^{\circ} \mathrm{C}$; $\mathbf{T N}<\mathbf{0}^{\circ} \mathbf{C}$ : Frosty nights - Number of days with daily minimum temperature $<0^{\circ} \mathrm{C}$; $\mathbf{T N}<\mathbf{5}^{\circ} \mathbf{C}$ : Cold nights - Number of days with daily minimum temperature $<5^{\circ}$.

Table A.7 Frequencies of maximum and minimum temperature extremes in some years in Lisbon. Data source: see Table 2.

\begin{tabular}{cccccc}
\hline Decades & TX25 & TX35 & TN20 & TN $<\mathbf{0}^{\circ} \mathbf{C}$ & TN $<\mathbf{5}^{\circ} \mathbf{C}$ \\
\hline $\mathbf{1 8 5 0}$ & 88 & 6 & 15 & 4 & 17 \\
$\mathbf{1 8 8 7}$ & 75 & 0 & 17 & 3 & 21 \\
$\mathbf{2 0 0 3}$ & 106 & 9 & 36 & 0 & 8 \\
$\mathbf{2 0 1 2}$ & 122 & 5 & 17 & 0 & 6 \\
\hline
\end{tabular}

TX25: Hot days - Number of days with daily maximum temperature $>25^{\circ} \mathrm{C}$; TX35: Very hot days Number of days with daily maximum temperature $>35^{\circ} \mathrm{C}$; TN20: Tropical nights - Number of days with daily minimum temperature $>20^{\circ} \mathrm{C}$; $\mathbf{T N}<0^{\circ} \mathbf{C}$ : Frosty nights - Number of days with daily minimum temperature $<0^{\circ} \mathrm{C} ; \mathbf{T N}<5^{\circ} \mathbf{C}$ : Cold nights - Number of days with daily minimum temperature $<5^{\circ}$. 